Article

\title{
The Freedom of Facticity
}

\author{
Abraham Olivier \\ Department of Philosophy, University of Fort Hare, Alice 5201, South Africa; aolivier@ufh.ac.za or \\ abrahamolivier@gmail.com
}

Received: 8 February 2018; Accepted: 30 March 2018; Published: 4 April 2018

\begin{abstract}
Here I am-Jew, or Aryan, handsome or ugly, one-armed, etc. I am all of this for the Other with no hope of changing it." Thus wrote Sartre in his Being and Nothingness. But was not Sartre the major advocate of existential freedom, with the tenet that "we are condemned to be free"-no matter what our situation might be? The question hence arises: How free are we from the facticity of situations, particularly ones in which we are subject to collective identification? How free are we to change the situations-places, environments, histories, others-that we inevitably belong to and which subject us to collective identities? How free are we from identification in terms of others? How free are we to transform such identification? These questions are of particular relevance given the harmful effects of collective ascriptions and the currently pressing demand to transform them. In an attempt to address these questions, I offer as alternative to Sartre's concept of the "facticity of freedom" what I would like to call the "freedom of facticity".
\end{abstract}

Keywords: Sartre; facticity; freedom; collective identification; liberation

\section{Introduction}

"The most decisive argument which is employed by common sense against freedom consists in reminding us of our powerlessness. Far from being able to modify our situation at our whim, we seem to be unable to change ourselves. I am not 'free' either to escape the lot of my class, of my nation, of my family, or even to build up my own power or my fortune or to conquer my most insignificant appetites or habits. I am born a worker, a Frenchman, a hereditary syphilitic or a tubercular" (BN p. 503). ${ }^{1}$

Thus spoke Sartre in his Being and Nothingness. On an even gloomier note, he adds:

"Here I am-Jew, or Aryan, handsome or ugly, one-armed, etc. I am all of this for the Other with no hope of changing it." (BN p. 544)

But was not Sartre the major advocate of existential freedom, with the tenet that "we are condemned to be free"-no matter what our situation might be?

The question hence arises: How free are we from situations, particularly ones in which we are subject to collective identification? More exactly, how free are we from the situations-places, environments, histories, others-that we inevitably belong to, and which subject us to collective identities? How free are we from identification in terms of others? How free are we to transform such identification?

This question is of particular relevance given the harmful effects of collective ascriptions and the currently pressing demand to transform them. In his response to Sartre, among others, Appiah offers a striking contemporary analysis of the effect and nature of collective identification in terms of what he

1 Henceforth Sartre's Being and Nothingness (Sartre 2003) is referred to as BN. 
calls "labelling" (Appiah 2003). ${ }^{2}$ Labelling includes what Du Bois ${ }^{3}$ called "badges of colour" such as "African", “Negro," "coloured race", "black", "Afro-American", or "Jewish-", “Italian-“, “Japanese-", "Korean-American", "gay", "lesbian", "straight". Labels or badges, so Appiah points out, collectively shape the way people conceive of themselves and their projects (Appiah 2003, pp. 436-37). Quoting Hacking (1992), Appiah shows how “... numerous kinds of human beings and human acts come into being hand in hand with our invention of the categories labelling them". ${ }^{4}$ Labelling has the harmful effect of imposing a set of committed criteria, which perpetuate a prejudiced ascription of collective identity, and involuntarily shape people's actions, plans, projects and lives altogether (Appiah 2003, pp. 438-39). Indeed, as Sartre put it, such collective identification has the effect of defining me in my "being-for-others" - I am put in a situation in which I become the Other-as-object; I become something I have not chosen to be (BN p. 545)..$^{5}$

Sartre offers one of the most radical and challenging but also most sophisticated classical philosophical notions of freedom and its primacy over and above the facticity of situations. ${ }^{6}$ This pertains particularly to situations of collective identification. Sartre's view of freedom has elicited a host of responses inside and outside philosophical literature, particularly within the framework of postcolonial discussions on ethics and politics, including contemporary scholars such as Taylor (1994), Appiah (2003), Alcoff (2006), Bernasconi (2007) and Gordon (1997, 2015), among others. Less attention has been paid to Sartre's phenomenological approach to freedom, and, actually, his key respondent still remains his own contemporary, Maurice Merleau-Ponty. ${ }^{7}$ My focus is on the phenomenological analysis of Sartre's view of freedom. Although I analyse Sartre's position in considerable detail and pay attention to, among others, Merleau-Ponty's response to Sartre, this paper is not primarily an attempt to revisit Sartre's work and add footnotes to the existing scholarly literature-as important as such an endeavour might be. Rather I aim to address the question concerning the relation of freedom to facticity by using Sartre's position in order to introduce an alternative to his concept of freedom. ${ }^{8}$ I argue that it is not as much despite, but rather because of the facticity of situations that there is what Sartre calls the freedom of choice. This alternative, so I contend, puts the discussion of freedom on another plane-at least within the framework of phenomenology.

The first part examines Sartre's view of "the facticity of freedom", while the second part introduces as alternative what I'd like to call "the freedom of facticity".

\section{Part 1: The Facticity of Freedom}

\subsection{The Freedom of Choice}

Common sense holds that the most decisive argument against freedom is our powerlessness against the adversities of circumstance. As Sartre puts it:

"Much more than he appears to 'make himself' man seems 'to be made' by climate and the earth, race and class, language, the history of collectivity of which he is a part, heredity, the individual circumstances of his childhood, acquired habits, the great and small events of his life." (BN p. 503)

\footnotetext{
See also Appiah's more recent 2016 BBC Reith Lectures, entitled Mistaken Identities.

Du Bois (1975, pp. 116-17) as referred to by Appiah.

Quote taken from Appiah (2003, p. 438).

Appiah accuses Sartre for not taking the theoretical commitments of collective identification seriously enough-I discuss his critique in Section 2.3 .

See Webber $(2011,327 f f)$.

Merleau-Ponty (1962). See the discussion of Webber (2011).

To be sure, I shall give a relatively lengthy discussion of Sartre's position first in order to make my use of and difference from his position clear. This discussion is also meant to help introduce the non-specialist to Sartre, while the specialist might prefer to glance at the first part of my paper and advance to the second part.
} 
Sartre rejects both classical responses to the common-sense view-libertarianism and determinism. He rejects both the idea that the will is infinite and therefore free to rule over circumstances and the notion that we are completely determined by circumstantial causes (BN pp. 458, 503). Sartre does not deny that freedom has circumstantial adversities; however, he argues that such adversities actually only arise because of the limits and ends that freedom itself posits. A crag, for instance, will manifest a profound resistance if I want to replace it, or else it can be a valuable aid if I want to climb upon it to look over the countryside (BN p. 504). Although brute things can limit our freedom of action from the start, it is only because of freedom that these things manifest as limits or ends (BN 504). This means, a subject is principally free to choose to determine its own limits and ends. Sartre thereby introduces what can be called a concept of autonomous freedom-the freedom of agency, of a subject to choose its own limits and ends of action; in short, the freedom of choice.

A common misreading of Sartre's position, so Webber (2011) points out, is that it comes down to some sort of "staccato voluntarism", meaning we decide capriciously how to respond to the world we encounter or how to make it appear. ${ }^{9}$ Sartre rather thinks of choice as an act of deliberation towards limited ends, that is, within the framework of projects (BN p. 505). As Webber notes, Sartre is not entirely clear on what is meant by "project". The term project is both a verb and noun and most basically refers to actions undertaken towards particular ends or possibilities. ${ }^{10}$ An example is a book project, the choice of the act of writing with the set possibility to complete a book. In its most general sense, a project encompasses life itself, including all our actions toward realising the possibilities of our choice. This resembles in core Heidegger's notion of a project as the projection of our "ownmost" possibilities, as described in Being and Time (Heidegger 1962, 183ff, BN pp. 482ff.). Thus, one can say, it is by choosing our "ownmost" possibilities that we are free; however, our choices are not whimsical but embroil limits between options as framed by projects.

Sartre's contention, that it is by choosing that we are free, does not mean that we choose to be free (p. 506). This distinction is at the heart of Sartre's phenomenology of freedom at the core of his monumental Being and Nothingness. Due to limited space, I confine myself to a rough outline of what seems to be the major thrust of his argument in the following. ${ }^{11}$

Sartre argues that freedom is not the product of choice, something we can choose to be or not to be, because it is rather a characteristic of what we are, as choosing conscious beings. What belongs to being conscious is to be free to turn what is given as mere thing, as non-conscious being, or what Sartre calls, "being-in-itself" (être-en-soi), into "being-for-itself" (être-pour soi)-into what this being means to oneself as subject (BN p. 19). Sartre follows Husserl's phenomenological view of consciousness as being structurally intentional, as being about and directed to things that are not itself. To be a subject means that, prior to any reflection or thetic decision, one is conscious of things, free to turn whatever thing one is conscious of into what this thing is not in-itself, thus into an object of consciousness (BN p. 53). Sartre argues that consciousness is thus directed toward a thing in a way free to "nihilate" it, to make out of it a thing "for" consciousness, which is in effect "nothing". Hence it is "nothing" but contents of consciousness. ${ }^{12}$ Consequently, consciousness turns everything into "nothing", nothing but meaning, which is the reason why Sartre equates consciousness with "nothingness" as opposed to "being".

This does not mean that consciousness turns everything into its own interiority, its inside project. As consciousness is intentional, it always transcends itself towards what is outside itself, so consciousness is actually out there in the world, abandoning itself to whatever it is directed to. In fact, as Sartre already argues in The Transcendence of the Ego, even the attempt of consciousness (the cogito)

9 Webber refers, among others, to Føllesdal (1981) charge against Sartre.

10 See, for instance, BN pp. 457 and 475. See also the key to special terminology in Being and Nothingness.

11 For a very basic but concise introduction to Sartre's theory of consciousness and freedom, see Cerbone (2006) and also Moran (2000).

12 BN pp. $40 \mathrm{ff}, 46 \mathrm{ff}, 99 \mathrm{ff}$. 
to conceive of itself as consciousness consists in turning itself into its own object (the ego) such that it will transcend its interior operations to become an exterior object among objects for itself outside itself in the world. ${ }^{13}$ As such, consciousness, as it were, remains in free flow, being constantly drawn beyond itself to whatever exterior objects it is directed. These things are, however, phenomenologically reduced to what they mean to the conscious subject. Hence, Sartre refers to objects in the outside world as the transcendental field of conscious awareness-they are out there but as what they mean to subjects.

Sartre's phenomenology of consciousness reverberates Heidegger's famous claim in Being and Time, which is that the human being is such that its being is an issue for itself. More particularly, humans are directed to things primarily as far as these things concern their own being and its possibilities. In a way similar to Heidegger, Sartre's phenomenology can be characterised as existential. This means that the human subject is directed to objects because of the possibilities it takes objects to have within the framework of its own projects (BN p. 502). A subject is free by choosing its own projects, thus by choosing what to make of its world and itself. In his Existentialism is a Humanism, Sartre confirms this point emphatically by stating the "first principle of existentialism"—or subjectivity—to be that "Man is nothing else but what he makes of himself" (Sartre 1965, p. 36). Sartre thus advocates what one can call the existential autonomy of freedom-the freedom to choose how to shape one's own being.

As a result, one can argue that, in Sartre's phenomenology, the subject's intentional focus on the object is ultimately played out in terms of existential meaning. "Intentional" thereby assumes a twofold meaning. It refers to the fact that (a) subjects direct themselves to objects (b) because of the envisioned projects of their choice. As far as consciousness consists in the autonomous freedom to nihilate objects by giving them existential meaning, one can also speak of it as existential freedom.

To summarise, I have shown that, in Sartre's view, freedom belongs to the nihilating capacity of consciousness to choose the meaning of things and so determine the way they appear (BN p. 53). To be conscious means to be directed to things other than ourselves with the freedom to act upon them, to nihilate them towards their possible meaning in our experience and for the sake of our own projects. It is in this sense that we qua subjects do not choose to be free, but rather, as conscious beings, we cannot but be free to choose to act upon the objects to which we are intentionally directed. In Sartre's words: "In fact we are a freedom which chooses, but we do not choose to be free." (BN p. 506). The intentional structure of consciousness renders us free to choose whatever meanings we attribute to them, whatever projects we make out of them, and we do not choose to be free in this way.

Sartre emphasises the contention that we do not choose our freedom by his famous claim that "we are condemned to freedom" (BN 506). We are condemned to be free and thus to make choices. The fact that we are bound to be free is actually the primary meaning of what he calls our facticity.

\subsection{The Facticity of Freedom}

Sartre's contention that we are condemned to be free-thus, to make choices-implies that we are bound to choose between options, and in this way set to meet the limits of our choices. He consequently defines freedom in terms of facticity. The "facticity of freedom" most basically means that one cannot but be free to choose; in short, that one is condemned to be free (BN p. 508). Facticity includes contingency. Contingency means that one cannot but exist, which means one is only free in relation to existents, to circumstances, to the given, to things and others in a particular situation, with regard to which one makes choices. ${ }^{14}$ In this extended sense, facticity means that one cannot but be free in relation to things and others in specific situations (BN p. 508).

13 Sartre (1957, pp. 93ff); BN pp. 97ff. See also Cerbone (2006, pp. 84ff).

14 Sartre maintains that facticity and contingency are really one (BN p. 508). Mostly he speaks of facticity, thereby including contingency. I shall follow his practice and use facticity in its extended sense including contingency. 
Facticity thus manifests in terms of what Sartre calls a "situation" (BN p. 509). He illustrates what he understands by a situation by using the example of considering whether a rock will lend itself to scaling. One is free to climb it, but this is contingent upon the limits the choice incurs. One is free to consider climbing it, or just admiring it; but one is bound to choose to view it in one way or the other. Depending on our choice, the rock will show particular limits either to our view or movement, which demonstrates how one's freedom is contingent upon circumstances (BN pp. 509-10). Because of my choice, there is a situation in which things will limit me and show me my limits, but it is from within these limits that I realise my freedom. Quoting Sartre:

"Thus we come to catch a glimpse of the paradox of freedom: there is freedom only in a situation, and there is a situation only through freedom." (BN p. 511)

Sartre concludes that human reality has a lot of obstacles and resistances not created by humans, but that these obstacles and resistances have their meaning only through the free choice which human reality is. To quote him:

"Thus our freedom itself creates the obstacles from which we suffer." (BN p. 516)

Conversely, freedom can only exist as restricted since freedom is choice. Every choice supposes elimination and selection, thus every choice confines options and therefore is a choice of finitude. This is what the facticity of freedom is exactly about: that we cannot but choose between finite options (BN p. 516). As Sartre puts it succinctly:

"Without facticity freedom would not exist-as a power of nihilation and of choice-and without freedom facticity would not be discovered and would have no meaning." (BN p. 517)

Sartre proceeds to discuss specific examples of a situation and its various structures-they are my place, my body, my past, my position, and my fundamental relation to the other (pp. 511ff.). I shall briefly discuss his view of the other, which he calls "my neighbour", in order to address the question as to how free we are from collective identification.

\subsection{Freedom and Identification}

It would be easy, Sartre says, if I would just belong to a world whose meanings were revealed simply in the light of my own ends. I would be the one by whom meanings would come to reality in itself. However, " . . there exist objective meanings which are given to me as not having been brought to light by me." (BN p. 531) I find myself engaged in a world which reflects to me meanings I have not put into it (BN p. 501). For example, rocks appear to be brutal things without any meaning, but we all learn that rocks are there to be climbed, or to build with, or to be admired; moreover, there are buildings out of rock with particular meanings and signs leading us to them, without us deciding their meanings (BN p. 532).

The question is, then, as Sartre puts it: "Am I not going to find in all this strict limits to my freedom"? (BN p. 532). How far do these meanings limit my freedom? Sartre states that clearly we cannot survive without submitting to a world with technically organised meanings (BN p. 532). I take collective ownership of instruments and techniques that organise my world. The world offers this countenance to everybody. Directions, instructions, orders, prohibitions, billboards organise a world to which I submit in order to realise my own specific projects (BN p. 532). As such, they make the facts of my facticity in its contingency. I cannot but be free, but I am free by adhering to given meanings others have attributed to reality (BN pp. 532-33).

The technical world that we share with others is clearly a defining feature of my own being and my freedom. ${ }^{15}$ As Sartre puts it:

15 In this sense, the typical accusation that Sartre's early work is overwhelmingly modernist and individualist, not allowing constitutive connections with others, as made by Alcoff (2006, p. 69), is not quite justified. 
"Belonging to the human species is defined by the use of very elementary and very general techniques. To know how to walk, to know how to take hold, to know how to pass judgment on the surface and the relative size of perceived objects, to know how to speak, to know how in general to distinguish the true from the false, etc." (BN p. 533)

A seminal feature of such techniques is the way they manifest in modes of speech. Speech is not universal but demarcated by a national collective language. And a national language, in turn, is not simply defined by academic dictionaries and grammars but practiced in particular regions, bound to the lingo of provinces, professions and families (BN p. 534). Consequently, so Sartre claims, the reality of speech is language and the reality of language is dialect, slang, jargon etc. Moreover, such language is imbedded in a reality of customs. For instance, to be French is not only to speak French, but is in reality to be a Savoyard, and to be a Savoyard implies a thousand of techniques to appropriate the world, for instance, skiing in the winters, and having very specific techniques of skiing needed specifically for the particular slopes of the valleys of Savoy. Using Heidegger's language, Sartre thus makes the point that one is always "thrown into" a world framed by collective technical meanings of some sorts—a French world, a workers' world, the world of the Savoy, etc.:

"I am not thrown only face to face with the brute existent. I am thrown into a worker's world, a French world, a world of Lorraine of the South, which offers me its meanings without my having done anything to disclose them." (BN p. 535)

Sartre concludes that I am free only in a particular place in the world, a situation in which I choose between existing options offered by collective techniques as shared with others in such a situation. Although I choose to take my own place in the world, I have no choice but to be in some place together with others (BN p. 541).

However, this does not mean that I simply have to submit to the existence of others and adopt existing meanings. On the contrary, one is compelled by one's condemnation to be free to make the other's existence manifest to oneself in the form of choice. In order to understand this point, it is important to consider Sartre's distinction between the choice to apprehend "the-Other-as subject" or "the-Other-as-object" (BN p. 541).

The Other-as-object manifests particularly in terms of collective identification. ${ }^{16}$ Through the upsurge of the other certain determinations arise, which I am without having chosen them. To repeat my initial quote:

"Here I am-Jew, or Aryan, handsome or ugly, one-armed, etc. I am all of this for the Other with no hope of changing it." (BN p. 544)

With this passage, Sartre clearly emphasises the limits to freedom set by objectifying forms of collective identification. Once again, such identification inevitably defines me in my "being-for-others"; in short, I become the-Other-as-object (BN p. 545). In this sense, I am something I have not chosen to be.

What is the result of such objectification for my freedom? Sartre argues that actually the limit imposed upon me by labelling does not per se come from the action of others. This limit does not as such dispossess us from our freedom. When we give in, we choose to do so, and it is an act of freedom (BN 545). Prohibitions like "No Jews allowed here, or Jewish restaurant. No Aryans allowed" refer to collective techniques which have meaning only on and through the foundation of my free choice. To quote Sartre:

16 This goes back to Sartre's famous analysis of the "Other-as-a-look" (BN pp. 276ff.) which I confine to my discussion of collective identification. 
"In fact, according to the free possibilities which I choose, I can disobey the prohibition, pay no attention to it, or, on the contrary, confer upon it a coercive value which it can hold only because of the weight which I attach to it." (BN p. 545)

The prohibition is based on a structure in which I am taken to be an object. Still, it loses its force within the limits created by my own choice not to attach weight to it (BN p. 545).

So how free are we really from being objectified by the other through labelling? On the one hand, Sartre makes clear our limits:

"The true limit of my freedom lies purely and simply in the very fact that an Other apprehends me as the Other-as-object and in that second corollary fact that my situation ceases for the Other to be a situation and becomes an objective form in which I exist as an objective structure." (BN p. 546)

This alienating process of objectification is a constant and specific limit of my situation, a way in which my "being-for-itself" is made a "being-for-others". Thus, I come to exist in a situation which has a dimension of alienation, which I can in no way remove from the situation any more than I can act directly upon it (BN p. 546).

Nevertheless, Sartre insists that the limit of my freedom exists fundamentally in my condemnation to choose, and when we include the other's existence, my freedom finds its limits also in the existence of the other's freedom. Sartre's argument comes down to the following: If the other chooses to make me an object, then this is because I choose to view the other as subject, free to make me an object; I choose to view the Other-as-subject. I can however choose to view the Other-as-object, not free to be a subject that can make me an object (BN pp. 546/7). As he puts it:

"It is only by my recognising the freedom of anti-Semites (whatever use they make of it) and by my assuming this being-a-Jew that I am a Jew for them; it is only thus that being-a-Jew will appear as the external objective of the situation." (BN p. 547)

So, the freedom of the other is what confers limits on my situation, but I can experience these limits only if I choose to take myself to be a being-for-others, that is, if I choose to give meaning to it.

The question still remains, to put it in Sartre's words:

"How then shall I experience the objective limits of my being: Jew, Aryan, ugly, handsome, king, servant, untouchable, etc. - when will language have informed me as to which of these are my limits?" (BN p. 548)

Sartre argues that it cannot be in the way I intuitively, through non-thetic or prereflective conscious perception, apprehend my qualities or project myself within the limits of my projects. Prereflectively, I am not for myself a waiter in the café, or a writer, or handsome or ugly. I do not spontaneously experience myself in this thetic way as somebody such as a waiter, or as handsome or ugly. In fact, I am not anything, I am nothing, unless I make myself an ego and object of reflection. So, even though we are lured by reflection into giving ourselves static identities such as in the case of labelling, our spontaneous experience will as such always escape any such objectification.

Alternatively, one can appropriate labelling in bad faith, that is, through self-denial, by taking toward oneself the point of view of the other (BN p. 549). But bad faith is also a choice, a choice to have meaning conferred on me. Others might, for instance, categorise me as Black, but I have the choice as to what I make of such a category; if I do nothing, I act in bad faith and actually choose to deny myself (BN p. 549). Ultimately, so Sartre claims, a Jewish or a black person chooses to be a Jew or a Black and this being a Jew or Black is nothing more than the free manner of adopting it (BN p. 550).

Sartre's conclusion is that, on the one hand, I cannot but assume my-being-for-Others, and in this sense we are condemned to the facticity of freedom; that is, we cannot but choose to be ourselves for others. Even if we abstain from or refuse to choose, we still make a choice, thus "whether in fury, hate, pride, shame, disheartened refusal or joyous demand", it is impossible for me not to choose to be what 
I am for others (BN p. 550). On the other hand, so Sartre emphasises his view, the only limits which freedom ultimately bumps up against at each moment are those which it imposes on itself (BN p. 552). In the final instance, one remains free not to allow the other to subject oneself to the imposition of his or her freedom on oneself through objectification (BN p. 552).

Let me point out some important critique of Sartre's position before moving on to the second part. Merleau-Ponty agrees with Sartre that I cannot but assume my being for others, and am not free to ignore them, but that I have the choice between being an object of disapproval or disapproving of others (Merleau-Ponty 1962, p. 505). However, Merleau-Ponty critically points out that this depends on the situation; for instance, a slave who succeeds in making his/her master an object cannot be really free if remaining a slave (Merleau-Ponty 1962, p. 507). Appiah makes a similar point. Following Hacking, he argues that Sartre does not take seriously enough the gravity of oppressive situations of collective labelling such as racism or sexism. Appiah confines himself to referring to Sartre's famous example of the waiter in the café, who has the choice to just play the role of a waiter without any strong commitments to identify with his role. Appiah argues that, in other settings, people lack such a choice; for instance, when a Feudal serf puts food on "my lady's table", he can no more choose to be a garçon de café than he can choose to be lord of the manor (Appiah 2003, p. 438). My contention is that the waiter is an overemphasised example of Sartre's view of the denial of either the limits of our situations or autonomy of freedom. Sartre offers several more serious examples of the binding effects of labelling. One such example is the issue of labelling people as Jews as discussed above. In fact, Sartre would agree with Appiah's point that when a Feudal serf puts food on "my lady's table", he can no more choose to be a garçon de café than he can choose to be lord of the manor. However, I agree with Merleau-Ponty and Appiah that, ultimately, Sartre does not adequately account for the need of oppressive situations to change as a condition of the possibility for subjects to be free. I discuss this point in the next part, particularly in the final Section 3.3 on "freedom and liberation".

\section{Part 2: The Freedom of Facticity}

\subsection{Autonomous and Heteronomous Freedom}

To resume, this paper raises the question as to how free we are from the situations-places, environments, histories, others-that we inevitably belong to and which subject us to collective identities. Sartre's claim is that we are condemned to freedom. Freedom always manifests in a situation, but firstly, it is because of freedom that we have a situation with its limits, and secondly, one can always be freed from a situation through the nihilating power of consciousness. Sartre thus resists the libertarian concept of absolute freedom by making it bound to a situation, but he also resists determinism by taking freedom to be the source of limits and options.

I want to put the discussion of freedom on another plane. I shall argue that it is not, in the first place, through freedom that we have a situation with limited options, but rather it is on the basis of a situation and the limits of its options that we are set free to have choices.

I have argued that Sartre contends that freedom is based on the nihilating ability of consciousness to choose what meaning objects (things or also others) take for the sake of our projects. Consciousness is always directed to objects in a situation. So, freedom always manifests in a situation in which we qua subjects direct ourselves to objects by giving them meaning within the framework of our projects. Sartre claims that consciousness is directed to objects. In effect, however, he reverses the direction of focus from the object back to the subject. The subject, which is claimed to be intentionally directed to the world outside itself, is in effect absorbed by projects concerning its own being in the world. Hence, objects ultimately assume existential meaning. In other words, our freedom is based on the autonomy of subjects to give objects the meaning of their existential choices. So, one can say Sartre advocates a concept of the existential autonomy of freedom.

I argue instead for a notion of what I call the intentional heteronomy of freedom. I agree with Sartre that freedom is based on and manifests in choice; however, I argue that choices are not in the 
first place the manifestation of the nihilating power of consciousness, but rather that they are originally based on and shaped by the options offered in particular situations. This argument will address the critique that Sartre does not adequately account for the need of oppressive situations to change as a necessary condition of the possibility of freedom.

In the remaining section, I aim to argue that we need to revert the intentional focus back from the subject to the object. My claim is that intentionality means to be originally directed by, rather than to, objects in particular situations because of their effect on us, and that objects will shape our choices, actions, and projects accordingly.

I argue this claim in two steps: first, I illustrate how choices between options are directed by objects in particular situations and their enabling conditions; second, more particularly, how choices between available options are learned in situations shared with others.

1. As a first step, I'd like to illustrate the above claim that choices are directed by objects and situations by taking Sartre's very own life as a sample case. In his autobiography Words (Les mots), Sartre wrote: "I began my life as I shall with no doubt end it: amidst books." (Sartre 1964, p. 40). According to his memoir, life began for Sartre in his grandfather's library. He recounts in detail how he developed a passion for books, specifically literature, during the ten years that he stayed in his grandparents' home after his father's death, and notably, his autobiography focuses on reflections on these years. He seems to have spent all his time in the library even before he could read. His grandfather, Charles, was a lycée professor of German and Sartre profited much from his grandfather's guidance. Charles held him in high regard, apparently as a prodigy, ${ }^{17}$ which prompted him to read and write novels. Despite critical intimations on Charles' intimidating authority, he ends his autobiography stating "I was saved by my grandfather." (Sartre 1964, p. 135) Sartre serves as a life-example of how someone was affected by certain objects: the books in his grandfather's library, in a specific enabling situation, the tutelage of his grandfather, which incited him to dedicate his life to projects of writing. His writing was as such influenced throughout by situations in his life. The events of the Second World, for instance, incited him to write a War trilogy with the significant title Roads to Freedom. The same can be said about the way his writings would then also come to reflect trends in Marxism in Marxism and Existentialism. Quite ironically, one can argue that Sartre's own life presents an anti-thesis to his theory that man creates himself; instead, he was shaped by objects (books) absorbing his attention and options given to him in particular situations (tutoring in the library), which formed and informed his choices and projects (to write particular books).

There are numerous other examples to demonstrate the same point, of how people are directed by specific objects in particular situations and their enabling conditions to choose to act exactly as they do and to pursue the projects around which their lives revolve-I point out some of these in the next step of the argument. At this point, one can argue that it is not that (a) subjects are directed to objects (b) because of the intended projects of their choice, but rather that (a) subjects are directed by objects (b) towards the intended projects of their choice. This means, freedom arises primarily from the options that objects in particular situations and their enabling conditions make us choose rather than from choices that are autonomously made. In a way, we can say our situation chooses us first before we choose it. ${ }^{18}$

2. The first step of my argument was to illustrate how choices between options are directed by objects in particular situations and their enabling conditions; the second step is to show, more particularly, how choices between options are learned in situations shared with others. The second step of my argument will consequently show that a seminal feature of the object-directed way to understand freedom is that choices are not primarily understood as self-made or autonomous but rather as other-made or heteronomous.

17 See Gordon (2015, p. 1).

18 This alludes to Merleau-Ponty's statement that the world chooses us and we choose the world, in his critical discussion of Sartre's concept of freedom in The phenomenology of perception. I come back to Merleau-Ponty's view in Section 3.2. 
As pointed out in the previous section (Section 2.3), Sartre rightly states that the "technical world" of meanings established by others is a defining feature of our own being and freedom. Belonging to the human species is defined by and requires that we learn to use elementary and general techniques. So, we learn to know how to walk, how to take hold, what to believe, how to pass judgment on perceived objects, how to speak, etc. (BN p. 533)—or, so one can add, how to choose to dedicate one's life to books like Sartre himself did under the tutelage of his grandfather. Actually, Sartre himself could just as well have argued that we learn that we have options to choose from, and more importantly, that we learn how to choose between options; therefore, that it is on this basis, on the basis of other-made options in a given situation, that choices are learned to be made in situations shared with others.

Many examples of what Sartre calls the "world of technical meanings" actually demonstrate this point. We learn in school to choose the right behaviour, to choose the right subjects for career purposes, we learn how to speak a language by choosing the right words, what to believe or how to reason, and we learn skills taken from the toolbox of logic to choose the best arguments; in short, we learn how to make choices between available options. We learn how to choose to take collective options while talking and acting in many different individual ways. Hence, the actions and projects of our choice are not, as Sartre argues, primarily autonomous, self-made, and as such projected within a given situation, but rather originally other-made, heteronomous, thus shaped by choices between options that others offer and that we learn to make in the enabling conditions of a situation.

This also goes for what seem to be original projects. So, for instance, any scientific project formulates its research question and aim or hypothesis of choice in response to options arising from the standing field of research. This is demonstrated by the expectation to offer a literature review and theoretical framework of major contributions to a given research field, and one's research project is required to address a lacuna in or contribute something new to the state of the art. One's choice of research is thus not originally self-made, it is in the first place other-made, no matter how original its approach and results might turn out to be. The same goes for the artist's choice of art works, which are always created in a way that responds to options that aesthetic traditions or their contemporaries have created. Consequently, one can say, I, the first-personal subject, do not primarily project meanings of my own choice into the world, but rather I learn to choose from options made available to me. Situations which I am thrown into enable me to have options from which I learn to choose.

We are in a position to draw the two steps of the above argument together into a conclusion now. The first step shows how choices between options are directed by objects in particular situations and their enabling conditions, the second step how one learns from others to choose between available options in such situations. In conclusion, one can say freedom is primarily heteronomous and consists of the way objects shared by others in specific situations form and inform our choices between options. In other words, it is not the autonomy but rather the heteronomy of choice that makes us free in the first place. Not my choice in a situation, but the situation itself, with the enabling conditions it offers in the form of options which it instructs me to take, is what primarily sets me free. One can thus say, it is on the basis of other-made choices alone that the freedom of self-made choices can exist. Thus, heteronomous choice has ontological priority to autonomous choice. Heteronomous choice does not exclude autonomous choice but precedes it.

\subsection{The Freedom of Facticity}

The argument is not yet complete. The question remains: how can one be really free if the options are all given and we have to learn how to take them?

In the following section, I address this question by briefly pointing out how far I agree with and differ from Merleau-Ponty's concept of freedom, which he develops as a critique of Sartre, and in this way show why exactly I speak of the "freedom of facticity".

In his famous chapter on freedom in his Phenomenology of Perception, Merleau-Ponty writes:

"What then is freedom? To be born is both to be born of the world and to be born into the world. The world is already constituted, but also never completely constituted; in 
the first case we are acted upon, in the second we are open to an infinite number of possibilities. But this analysis is still abstract, for we exist in both ways at once. There is, therefore, never determinism and never absolute choice, I am never a thing and never bare consciousness. In fact, even our own pieces of initiative, even the situations which we have chosen, bear us on, once they have been entered upon by virtue of a state rather than an act. The generality of the 'rôle' and of the situation comes to the aid of decision, and in this exchange between the situation and the person who takes it up, it is impossible to determine precisely the 'share contributed by the situation' and the 'share contributed by freedom'." (Merleau-Ponty 1962, p. 527)

Merleau-Ponty opposes the extremes of both determinism and libertarianism (or as he calls it, "idealism"), of admitting absolute priority to either facticity or freedom. According to him, facticity (the situation) and freedom are like magnetic poles kept in the tension of constant exchange. As he puts it, " ... even the situations which we have chosen, bear us on" (Merleau-Ponty 1962, p. 527). Hence, " . . . it is impossible to determine precisely the 'share contributed by the situation' and the 'share contributed by freedom.'" (Merleau-Ponty 1962, p. 527). I am neither determined nor absolutely free, it is impossible to say whether I choose because of my situation or because I am free to decide. I am a project of the world that I project myself (Merleau-Ponty 1962, pp. 499-500).

Contrary to Sartre, Merleau-Ponty argues that it is not due to choice that we experience the world with limits and options, but rather we are "born into" experiencing it with its limits and options. Consider Merleau-Ponty's example of a worker deciding to become proletarian (Merleau-Ponty 1962, p. 514). A worker neither chooses to be a proletarian, nor is he born into the proletarian movement, but rather in dealing with his situation and others in his situation, the worker adopts his situation as his existential, proletarian project. Freedom arises through such an existential project, through which, together with others with whom I share a past and present, I give my life direction.

Merleau-Ponty puts more emphasis than Sartre on the share that the situation contributes to freedom, but as for Sartre, the situation ultimately remains an existential project for him too, one in which subjects deal in a way with the world that makes it their project, one in which they are primordially free to direct their lives. The fact that the subject inhabits—or, as Merleau-Ponty says, embodies-a situation as its existential project admits the priority of its freedom over and above the facticity of the situation.

My position differs from Merleau-Ponty's in two respects:

Firstly, instead of thinking of the facticity of the situation and freedom in terms of two poles in tension, I argue that the situation as such entails freedom by virtue of the way it offers us choices and shapes the way we choose. If we claim that choice constitutes freedom, and that a situation enables and teaches us to choose, it follows that the situation must entail choice and consequently freedom. To return to Merleau-Ponty's example: instead of saying a worker becomes part of the proletariat by dealing with other workers, one can rather say the worker is directed by social conditions to start dealing with other workers and consequently to be brought to understand and make the choice to join the proletarian movement, thus to deliberately decide to become a proletarian, and to play his/her individual role as part of this collective project.

Secondly, by taking facticity to entail freedom in a way that originally directs choice, my own position to some extent inverses this priority of freedom over facticity. This comes down to setting a difference in ontological priority. I agree that freedom coincides with choice but argue that facticity gives rise to choice in the first place. Like Sartre, albeit in a more moderate way, Merleau-Ponty prioritises the autonomy of choice. I prioritise the heteronomy of choice. In this sense I speak of the freedom of facticity.

In order to be clear on why I think facticity entails freedom, it is important to consider the meaning of what we might take to be the limits of situations. It is helpful to view limits in terms of the Greek term for limit, $\pi \hat{\varepsilon} \rho \alpha \sigma$ (peras), which, as Heidegger insightfully showed, bears the meaning of 
“opening" (Heidegger 1971, p. 154). ${ }^{19}$ Limits in this sense can assume various meanings and it will require a study of its own to explore these meanings. Take the example of a game: limits in many ways "open the game", making it possible by, for instance, outlining the borders of the playfield or sportsground, making divisions between teams, prescribing rules, restricting movement, navigating manoeuvres, charting chances and altogether by demarcating its beginning and end. Limits are in this sense essentially part of the condition of the possibility to play, they, as it were, open the game by delineating its options. One can say, they define rather than confine a game. In other words, limits can be said to delineate and direct the options of choice by virtue of which situations make freedom possible. Hence, contrary to Sartre, one can say, it is not in the first place because of the freedom of choice that situations have limits, but rather situations give choices the limits that define our freedom.

However, as should be clear, this argument should not be mistaken to deny the autonomy of freedom. On the contrary, while it is necessary for subjects to have learned to choose between options offered by situations, for freedom to unfold sufficiently, it is obvious that subjects must actually make their own choices between such options or choose to create new options of their choice. Consider a situation like a game again: while the game primarily gives subjects the options (tactics, manoeuvers, etc.) to choose and thus grant them the necessary freedom to play, one still needs individuals making their very own choices between these options for the game not to be manipulated but to allow what is typically called free play.

In conclusion, one can say, freedom has a heteronomous origin with an autonomous dimension. Primarily, a situation enables us to have heteronomous freedom; we are driven, drawn in, pushed by objects and situations like, for instance, in the case of games, to make choices. In this sense, one can say, a situation and the options it offers is the fulfilment of the necessary condition for heteronomous freedom. Secondarily, we have autonomous freedom, which manifests in our choosing between the options situations offer, or choosing to change or create new options in given situations. Ultimately, one can say, a situation as such is a necessary but not sufficient condition of the possibility to be free. The freedom of the situation and its other-made choices require the freedom of self-made choices to sufficiently fulfil the condition of the possibility of freedom.

\subsection{Freedom and Liberation}

Ideally, the limits of situations, rather than to confine, will disclose possibilities of choice. But this is ideally the case, for there are some situations that can seriously oppress possible options of choice. One of these is the limitations set by collective labelling. The concluding question is how the notion of heteronomous freedom can help address the problem of collective identification. How free are we really from situations that subject us to collective identification?

Sartre has a fascinating suggestion: do not allow the other to be free to subject you to objectification. But how free are we to do this? His suggestion assumes that people principally always have the possibility to autonomously make their own, self-made or "authentic" choices, choices to be made no matter what the situation is. The privation of authentic choices is what Sartre famously calls "bad faith", self-denial (BN pp. 70ff). As we are condemned to be free, Sartre believes that we always have a choice not to submit to labelling, no matter what the situation might be. Even to surrender oneself to a situation, to resign, or not to choose, manifests the freedom of choice. Sartre's belief in the condemnation to autonomous freedom is, no doubt, fascinating, but, as Merleau-Ponty indicates, suffers from an idealistic overemphasis of the autonomy of freedom despite, and over and above, the facticity of the situation.

A situation can narrow down our options of choice to a bare minimum, to a point such that we can hardly speak of authentic choices without resorting to idealism. What options remain to choose from authentically, for instance, for soldiers condemned to death in a train to the concentration

19 See also the discussion of Malpas (2006, p. 254). 
camps, as Sartre describes in poignant detail at the end of Troubled Sleep (Sartre 1986), the second novel in his trilogy, Roads to Freedom? Closer to home, what authentic choices remain in a place like a township, an informal settlement consisting of shacks, with a serious unavailability of basic options in terms of protection, nourishment, water supply, education, and medical resources? In a recent paper, "Heidegger in the township", I have attempted to demonstrate in extensive detail how people in a township, specifically so called "shanty towns", are faced with a disenabling rather than enabling situation, deprived of the most basic options and possibilities of choice (Olivier 2015). Only in rare, exceptional cases will people have the extraordinary ability to be free, or to escape, despite their limits in such a situation. So, if collective identification translates into laws that enforce the badge of colour on people to the extent that they are expulsed to disenabling places, like shack towns, bereft of possibilities, the heteronomy of freedom in such a situation makes the autonomy of freedom impossible. Then, to insist that we are condemned to be free seems to result in existentialist idealism.

If the heteronomous freedom offered by situations is the necessary condition of the possibility for autonomous freedom, then a situation must fulfil this condition for autonomous freedom to be. If a situation cannot satisfy this condition, there will be no autonomous freedom; thus, for freedom to be, such a situation will have to be transformed as a whole. In the case of an oppressive situation such as collective labelling, freedom only manifests if the situation itself is transformed in a way that heteronomous choices become collectively available. For instance, to release an individual such as Mandela from jail was of seminal importance, not so much because the confines of imprisonment were removed and he was offered individual liberty, but rather because his release was a symbol of the collective liberation of the majority of the people suffering under collective labelling under apartheid legislature.

At this juncture, it is perhaps helpful to recall Fanon's distinction between liberty, as the removal of individual constraints, and freedom, as taking collective responsibility for one's choices in a situation. ${ }^{20}$ In his Existentialism is a Humanism, Sartre actually seems to argue along the same lines that individual choice necessarily implies collective responsibility. Using this distinction, one can argue that it is not enough to guarantee the liberty of some individuals in order to obtain freedom, but rather a whole situation, which people collectively bear, needs to be transformed for freedom to be possible. Decolonisation is, according to Fanon, an example of such transformation needed for the liberation of the situation of colonial oppression (Fanon 2004, p. 11). ${ }^{21}$ In this sense, one can usefully distinguish between liberty and liberation as between removing individual constraints and transforming a collective situation. Liberation, the transformation of the situation, is needed if a situation oppresses rather than offers options of choice. Thus liberation, rather than liberty, is needed for freedom to exist. Only such liberation can meet the necessary condition of the possibility of heteronomous freedom, the other-made choices that enable us to have self-made choices.

Some questions remain: How do we recognise and also change situations of oppression? How do we avoid such transformation to become a form of oppression itself, as scholars such as Freire (2000), Appiah (2003) or Alcoff (2006) challenge us to ask? What role does power or education play in such transformation? Due to limited space, these questions will have to be addressed in another study. Such a study will require more focus on Sartre's later works and the idea of resocialisation, such as developed in his Critique of Dialectical Reason (Sartre 1982), and a discussion of works such as Freire's idea of educating transformation in his book The pedagogy of the oppressed. But that will need to wait for another time.

20 Lewis Gordon helpfully points out this distinction (Gordon 2008, p. 83).

21 Fanon explicitly refers to liberation in terms of the transformation of the situation, particularly, the decolonisation of the situation (Fanon 2004, p. 2) versus the liberties taken by the colonisers (pp. 33, 50). 


\section{Conclusions}

I agree with Sartre that freedom is defined by choice, but I disagree that freedom is based on autonomous choice in a given situation. I argued that, primarily, we have heteronomous freedom by virtue of situations enabling us to have options of choice. Secondarily comes autonomous freedom, which manifests in what we make of situations, how we choose options by taking or changing them or by creating new ones. Consequently, individuals cannot be sufficiently free if oppressive situations that legitimise collective labelling, such as racism, are still allowed to exist. Some individuals free themselves from such situations because they obtain exceptional options or have extraordinary abilities, but if these situations are not changed, individual actions do not necessarily constitute freedom. Conversely, a situation as such is a necessary but not sufficient condition of the possibility for freedom. The freedom of the situation and its other-made choices requires the freedom of self-made choices to qualify sufficiently as freedom. But we are in bad faith if we deny that we need situations to set us free to make autonomous choices, and that if we do not have such situations, they need to be liberated first. Thus, heteronomous freedom is the necessary but not sufficient condition of the possibility for autonomous freedom.

Acknowledgments: All sources of funding of the study should be disclosed. Please clearly indicate grants that you have received in support of your research work. Clearly state if you received funds for covering the costs to publish in open access. Research work for this paper was done during a Sabbatical in 2017. I received travel grants in support of the presentation of my research work from projects funded by the Social Sciences and Humanities Research Niche Area at Fort Hare, Leverhulme Trust at the London School of Economics, DAAD (German Academic Exchange Service) at the Institute of African Studies (Afrikanistik) at the University of Bayreuth, and as keynote at the conference this special issue is based on.

Conflicts of Interest: The author declares no conflict of interest.

\section{References}

Alcoff, Linda Martín. 2006. Visible Identities: Race, Gender, and the Self. Oxford: Oxford University Press.

Appiah, Kwame A. 2003. Race, culture, identity. In The African Philosophy Reader. Edited by P. H. Coetzee and A. P. J. Roux. New York: Routledge, pp. 373-91.

Bernasconi, Robert. 2007. How to Read Sartre. London: Granta Books.

Cerbone, David R. 2006. Understanding Phenomenology. Chesham: Acumen.

Du Bois, William Edward Burghardt. 1975. Dusk of Dawn: An Essay toward an Autobiography of a Race Concept. Milwood: Kraus-Thomson Organization Limited.

Fanon, Frantz. 2004. The Wretched of the Earth. New York: Grove Press.

Føllesdal, Dagfinn. 1981. Sartre on Freedom. In The Philosophy of Jean-Paul Sartre. Edited by P. A. Schilpp. La Salle: Open Court, The Library of Living Philosophers.

Freire, Paulo. 2000. Pedagogy of the Oppressed. London: Continuum, New York: Continuum.

Gordon, Lewis R. 1997. Black Existential Philosophy. In Existence in Black: An Anthology of Black Existential Philosophy. Edited by L. Gordon. New York: Routledge.

Gordon, Lewis R. 2008. An Introduction to Africana Philosophy. Cambridge: Cambridge University Press.

Gordon, Lewis R. 2015. Sartre. In The Encyclopedia of Political Thought, 1st ed. Edited by Michael T. Gibbons. Somerset: John Wiley \& Sons, Ltd.

Hacking, Ian. 1992. Making up People. In Forms of Desire: Sexual Orientation and the Social Constructionist Controversy. Edited by Edward Stein. New York: Routledge, pp. 69-88.

Heidegger, Martin. 1962. Being and Time. Translated by J. Macquarrie and E. Robinson. Oxford: Blackwell. Heidegger, Martin. 1971. Poetry, Language, Thought. Translated by A. Hofstadter. New York: Harper and Row. Malpas, Jeff. 2006. Heidegger's Topology. Cambridge: The MIT Press.

Merleau-Ponty, Maurice. 1962. Phenomenology of Perception. Translated by C. Smith. London and New York: Routledge. Moran, Dermot. 2000. Introduction to Phenomenology. London and New York: Routledge

Olivier, Abraham. 2015. Heidegger in the Township. South African Journal of Philosophy 34: 240-54. [CrossRef]

Sartre, Jean-Paul. 1957. Transcendence of the Ego. Translated by F. Williams and R. Kirkpatrick. New York: Noonday Press. Sartre, Jean-Paul. 1964. Words. Translated by B. Frechtman. New York: Braziller. 
Sartre, Jean-Paul. 1965. Essays in Existentialism. Edited by W. Baskin. Secaucus: Citadel Press.

Sartre, Jean-Paul. 1982. Critique of Dialectical Reason. Translated by A. Sheridan-Smith. London: Verso.

Sartre, Jean-Paul. 1986. Troubled Sleep. Translated by E. Sutton. London: Penguin.

Sartre, Jean-Paul. 2003. Being and Nothingness. London: Routledge.

Taylor, Charles. 1994. Multiculturalism and 'The Politics of Recognition'. Princeton: Princeton University Press.

Webber, Jonathan. 2011. Freedom. In The Routledge Companion to Phenomenology. Edited by S. Luft and S. Overgaard. New York: Routledge, pp. 327-35. 